\title{
THE DISCRIMINANT ANALYSIS APPLIED TO THE DIFFERENTIATION OF SOIL TYPES
}

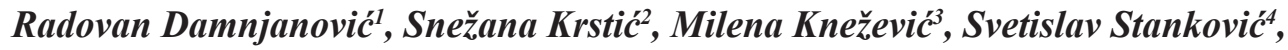 Dejan Jeremic ${ }^{5}$}

\section{Summary}

It is frequently important in agroeconomics, on examing form example in plant breeding the problem might be to decide whether a plant or plant progeny belons to a high-yealding or low-yealding grop up.

Sometimes decisions can be made on the basic of a single varialble, but more often of the 2 group differ in several variables, each of which gives some indication as to group in which the individual should be placed. This is a clasical problem of discrimination, where the general problem is to find a disrimination function.

Key words: analysis, differentiation, soil, types, plant.

JEL: $C 25, C 35$.

\section{Introduction}

According to Kardaun, et al. (1993), the theory of discriminant analysis is a well developed branch of statistics and at the same time still a field of active research. Part of the algorithms are implemented in special or general statistical packages. One can approach discriminant analysis from a purely data-descriptive point of view and from a probabilistic point of view (Both approaches, but most easily the latter one, can be incorporated into a decision theoretical framework). In the latter approach, a probabilistic model is used to describe the situation. The applicability of such a model in non-random situations may be questioned

1 Radovan Damnjanović, PhD. Assistant Professor, Military Academy, University of Defence, Belgrade, Pavla Jurišića Šturma 33, 11000 Belgrade, Serbia, E-mail: radovandam78@gmail.com

2 Snežana Krstić, Ph.D., Associate Professor, Military Academy, University of Defence, Belgrade, Pavla Jurišića Šturma 33, 11000 Belgrade, Serbia, E-mail: snezanakrstic17@gmail.com

3 Milena Knežević, PhD., University of Defence, Belgrade, Pavla Jurišića Šturma 33, 11000 Belgrade, Serbia.

4 Svetislav Stanković, PhD. Assistant Professor, Military Academy, University of Defence, Belgrade, Pavla Jurišića Šturma 33, 11000 Belgrade, Serbia.

5 Dejan Jeremić, PhD. Assistant Professor, Sequester Employment, Palmotićeva br. 22, 11000 Belgrade, Serbia, E-mail: office@sequesteremployment.com

EP 2017 (64) 4 (1513-1521) 
from a fundamental point of view (Breiman et al., 1984) However, such a probabilistic framework is almost indispensible if one wants to estimate the performance of procedures in future situations, and to express uncertainties in various estimates.

Moreover, it often leads to procedures that are also sensible from a data-descriptive point of view(Chercassky, Mučier, 2007). Or reversely: A specific procedure can often be viewed upon as a data-descriptive one, with little further interpretation, and as a probabilistic one, with considerably more interpretation, the validity of which is of course dependent on the adequacy of the framework.

Sometimes a procedure developed in one probabilistic framework can also be interpreted in another probabilistic framework, which may be more relevant for the data at hand (Farlov, 1984; Forsyth, 1989; Gilad-Bachrach, 2006; Gilad-Bachrach,2004).

Thanh et al. (2017) show that there has been a great effort to transfer linear discriminant techniques that operate on vector data to high-order data, generally referred to as Multilinear Discriminant Analysis (MDA) techniques. Many existing works focus on maximizing the inter-class variances to intra-class variances defined on tensor data representations. However, there has not been any attempt to employ class-specific discrimination criteria for the tensor data. In this paper, they propose a multilinear subspace learning technique suitable for applications requiring class-specific tensor models. The method maximazes the discrimination of each individual class in the feature space while retains the spatial structure of the input.

Early on, Beauchamp et. al (1980) implemented discriminant anlaysis method to uranium exploration. It is possile to use discriminant analysis methods on hydrogeochemical data collected in the NURE Program to aid in fomulating geochemical models that can be used to identify the anomalous areas used in resource estimation. Discriminant analysis methods have been applied to data from the Plainview, Texas Quadrangle which has approximately 850 groundwater samples with more than 40 quantitative measurements per sample. Discriminant analysis topics involving estimation of misclassification probabilities, variable selection, and robust discrimination are applied(Hart, 1989; Haussler, 1989; Han \& Camber, 2000; Kantardzic, 2011). A method using generalized distance measures is given which enables the assignment of samples to a background population or a mineralized population whose parameters were estimated from separate studies (Milojević et al., 2013; Vukoje, 2013; Stanojević et al., 2017).

Also, Zhijin, et al. (1994) used the discriminant analysis method in multivariate statistical theory to handle the e $\pi \mu$ separation in BES, describing the principle of the discriminant analysis method, deriving the unstandardized discriminant functions (responsible for particle separation), giving the discriminant efficiency for e $\pi \mu$ and comparing the results from the discriminant analysis method with those obtained in a conventional way. 


\section{Data and Variables}

Our data collected 286 samples of soil of which 100 contained the organism Azotobacter and 186 did not. Characteristics of the soil were suded:

$\mathrm{X}_{1}=\mathrm{pH}^{6}$

$\mathrm{X}_{2}=$ amount of redealy avaiable phosphate

$\mathrm{X}_{3}=$ total nitrogen content

Data are colected from Iowa Agriculture Experimentation Statsion, Cox and Martin (1) In our case, a sample for X1, X2, and X3 was taken to 52 samples of the earth. Group A had 25 samples and contained Azotobacter, while Group B had 27 samples and did not contain Azotobacta.

\section{Methods}

In our case, we will use discriminatory analysis in order to evaluate the difference in soil diversity. In other words, through the knowledge of 3 characteristics $\mathrm{X} 1, \mathrm{X} 2$, and X3, through formal presentations in our case, the application of discriminatory analysis can make significant indications whether the soil sample contains or does not contain the organism Azotobacter . Respecting the fact that Aztobacter positively affects agriculture products, which is not a matter of our consideration. For the purposes of our research, we have identified the use of stepwise discriminant analysis for the purpose of determining a variable that is decisive for the classification procedure (Kohavi, 1995; Quinlan, \& Cameron-Jonas, 1995; Koteri \& Lester, 2012), whether the type of soil contains or does not contain the bacterium Azotobacter. The first step in our analysis is the application of linear discriminatory analysis.

\section{Linear Discrimination Analysis-LDA (Supervised Learning)}

The first step in the classification process is the application of LDA in the application of the Data Mining method - finding drowned knowledge(Written \& Frank, 2005), which presupposes learning on the sample, produced the following results:

We only hold on the confusion matrix, which indicates a resubstitution error of the order of $12 \%$. A detailed analysis of the results shows that some variables are not important in the process of determining the presence of Azotobacter.

6 The $\mathrm{pH}$ value is the measure of the activity of hydrogen ions $(\mathrm{H}+)$ in the solution and thus determines whether a solution is of acid or base character. The $\mathrm{pH}$ value is dimensionless, and for the comparison, a $\mathrm{pH}$ scale of values ranging from 0 to 14 is used. For acid solutions, the $\mathrm{pH}$ is less than $7(\mathrm{pH}<7.0)$, and for bases it is greater than $7(\mathrm{pH}>7,0)$

EP 2017 (64) 4 (1513-1521) 
Table 1. Classifier performances

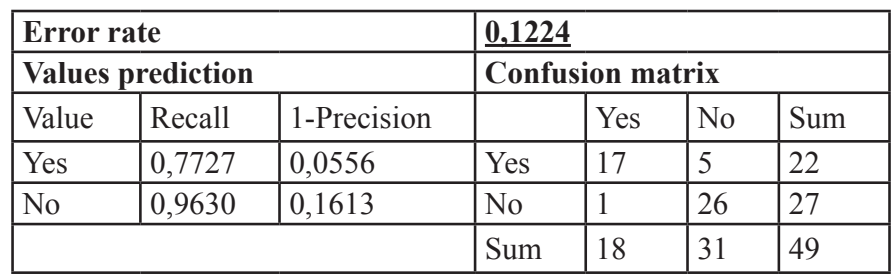

Source: authors' calculations;

The classification function would be, as follows:

$\mathrm{Z}=21.5 \mathrm{X} 1-0.07 \mathrm{X} 2+0.03 \mathrm{X} 3-76$

The question arises as to whether the variables X2 and X3 should be rejected from the analysis as insignificant for our classification process.

Although the error is optimistic, we approach the use of resampling methods called bootstrap I which gives a better assessment of the classification potential.

Table 2. Boostrap error estimation

\begin{tabular}{|l|r|}
\hline \multicolumn{2}{|c|}{ Error rate } \\
\hline$\underline{\mathbf{6 3 2}+\text { bootstrap }}$ & $\underline{\mathbf{0 , 1 4 2 9}}$ \\
\hline .632 bootstrap & 0,1423 \\
\hline Resubstitution & 0,1224 \\
\hline
\end{tabular}

Source: authors' calculations;

We see that the actual error is significantly higher than the initial error.

Otherwise in the classification process is the application of stepwise discriminant analysis, with the results as follows:

Table 3. Detailed results

\begin{tabular}{|c|c|c|c|c|c|c|c|}
\hline $\mathbf{N}$ & d.f & Best & \begin{tabular}{|l|} 
Sol.1 \\
\end{tabular} & \begin{tabular}{|l|} 
Sol.2 \\
\end{tabular} & \begin{tabular}{|l|} 
Sol.3 \\
\end{tabular} & \begin{tabular}{|l|} 
Sol.4 \\
\end{tabular} & \begin{tabular}{|l|} 
Sol.5 \\
\end{tabular} \\
\hline 1 & $(1,47)$ & $\begin{array}{l}X \\
L: 0,45\end{array}$ & $\begin{array}{l}X \\
L: 0,4565 \\
F: 55,95 \\
p: 0,0000\end{array}$ & 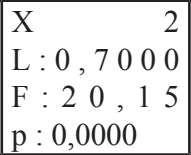 & 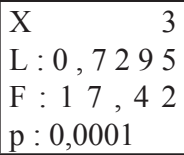 & - & $1-$ \\
\hline 2 & $(1,46)$ & - & $\begin{array}{llr}X & 3 \\
L & : & 0,4444 \\
F & : & 1,26 \\
p & : & 0,2679\end{array}$ & 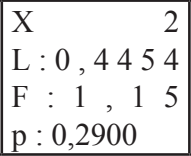 & 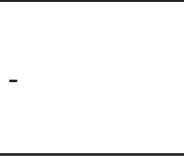 & - & - \\
\hline
\end{tabular}

Source: authors' calculations;

Using forward strategy, we obtained for F statistics 3.84 that there is only one relevant variant $\mathrm{X} 1=\mathrm{pH}$.

The third step in the analysis is the re-implementation of the LDA, which in this case gives the same classification error, but with a discriminatory function, as follows: 
$Z=19.5 X 1-71.5$

Again, using the bootstrap validation we came up with a similar error of $13 \%$.

Application of the LDA and STEPDISK classification indicates that after the application of the Data Mining method, the so-called. The supervised learning came to a single chrysal variable that, in combination with a constant, has a dominant effect on determining whether the type of soil contains or does not contain Azotobacter.

The next section of the appendix has the purpose to define how many "potentials" influence the classification variables through the application of the Decision Trees.

\section{Application of Decision Trees}

Learning the decision tree is the process of creating a discriminating function in the form of a decision tree $(1,8),(2,995-1003),(18,404)$. The tree is created recursively, from the top (roots) to the leaves, so each tree node represents a logical test of the value of an attribute from the description of the problem, and leaves represent the class in which the example is classified. When creating, the assortment of attributes for each node is done by heuristic methods, based on the assessment of the quality of discrimination (under) of a set of examples from the training session, remaining for discrimination in the observed node. Although a tree can perfectly classify all the cases from a training session, it does not represent a high accuracy guarantee on new examples, as they are often overfits according to training examples, so simplification is made, resulting in smaller trees, which are more accurate at the same time and more comprehensible. In our analysis, we used wellknown decision-making algorithms, C4.5 (16,287), which are available within the WEKA (University of Waikato) system (19) for the purpose of selecting associated attributes. The main advantage of the decision tree is to provide a significant way of presenting knowledge by extracting IF-THEN classification rules.

The results obtained indicate a level of accuracy of $90 \%$ versus an error of $10 \%$.

\section{Decision tree}

- $\quad \mathrm{X} 1<6.8000$

- $\mathrm{X} 1<5.7500$ then contains Azotobacter $=$ No $(100.00 \%$ of 9 examples $)$

- $\mathrm{X} 1>=5.7500$

- $\mathrm{X} 2<34.0000$ then contains Azotobacter $=$ No $(90.91 \%$ of 11 examples

- $\mathrm{X} 2>=34.0000$

○ $\mathrm{X} 1<6.1500$ then contains Azotobacter $=$ Yes $(60.00 \%$ of 5 examples)

○ $\mathrm{X} 1>=6,1500$ then contains Azotobacter $=$ No $(83.33 \%$ of 6 examples)

- $\quad \mathrm{X} 1>=6.8000$ then contains Azotobacter $=$ Yes $(94.44 \%$ of 18 examples $)$ 


\section{Attribute selection methods}

The formation of an adequate model is based on the knowledge of the problem and is often reduced to the selection of the corresponding set of attributes. The existence of irrelevant and redundant (irrelevant, surplus) attributes in the problem model negatively influences the performance of most of the inductive learning methods, and such attributes are often removed from consideration by the method of previous or embedded selection of attributes (2). The optimal set of attributes contains all relevant attributes, while redundant and irrelevant attributes are usually excluded from consideration, although poorly relevant redundant attributes potentially contain information that can affect the improvement of classifying performance in practice (2), (4), (9). In the attachment, some methods of the previous selection of attributes embedded in the WEKA system (19) will be used to further check the significance of individual attributes from the problem model.

Results WEKA Selection of the Attribute. With different methods of searching and evaluating attribute subsets, the best subgroup is found, which gives the most accurate rules (trees). Some of the methods for individual attributes also give numerical estimates.

Method Relieff (evaluates each attribute separately), gave the following results:

Table 4. Detailed results

\begin{tabular}{|c|c|c|}
\hline $\mathbf{N}$ & Attribute & Weight \\
\hline 1 & $\mathrm{X} 1$ & 0,175578 \\
\hline 2 & $\mathrm{X} 3$ & 0,054731 \\
\hline 3 & $\mathrm{X} 2$ & 0,048435 \\
\hline
\end{tabular}

Source: authors' calculations;

The Relieff method estimates that the most important attributes are hierarchically compared: $\mathrm{X} 1=\mathrm{pH}$.

\section{Conclusion}

Agroeconomics is facing increasing challenges, especially in the domain of research not only on the quality of land, but also on other food resources as sources of organic food. Methods of finding hidden knowledge have a presumption in relation to classical methods because they more precisely classify, and have higher predictive capacities.

The aim of this study is to examine the usefulness and exactness of these methods in the case of examining the presence of an asteroid in the soil or non-existence (category "yes" and "no") based on the sample examination. Supervised Linear Discimination Analysis was used to identify the specific effect of variables on the presence versus non-deposition of the Azotobacteria with methods of validating the accuracy of the classification of the effect of variables and identifying the key variables in this case, this is the presence of $\mathrm{pH}$. In addition to this method, the Decision Tree was used, which gave results that are more precise in terms of determining the level to which the influence of individual 
variables is. The data obtained are accurate at the level of $90 \%$ and unlike conventional multivariate research, this is a survey where the influence of four variables on the presence of Azotobacteria from which three variables are not decisive for qualification is improved by means of the supervised analysis. Everything that the research put into the foreground was achieved and this is a great degree of research accuracy (level of 90\%).

The RILIEF method - the selection of the attribute clearly defined the supremacy of the $\mathrm{pH}$ - factor effect, while the impact remained two relatively minor values of about $5 \%$ respectively. The use of this methodological tool would greatly help researchers in the field of agriculture, especially because of the possibility for research to be carried out on scarce training sessions with a large number of attributes (characteristics of the subject of research, eg land, quality of agricultural products, fruits, vegetables, eggs, meat I many others) and very few examples (the so-called scarce rallies). The problem of scarcity is related to the task difficulty assessment, which is dealt with in the Domain Data Mining domain by reducing the number of attributes (variables). Such methodological approaches enable the discovery of hidden knowledge in agronomy and agroeconomics, and primarily in the causes that determine the key - determined variables and attributes and factors for solving research problems and correct hypothesis, both in the field of agronomy and in other fields of research.

\section{Literature}

1. Beauchamp, J.J., Begovich, C.L., Kane, V.E. \& Wolf, D.A. (1980): Application of discriminant analysis and generalized distance measures to uranium exploration, Journal of the International Association for Mathematical Geology; vol. 12, No. 6, pp. 539-558.

2. Breiman, L., Friedman, J.H., Olshen, R.A., Stone C.J. (1984): Classification and Regression Trees, Wadsworth, Belmont.

3. Chercassky, V., Mučier, F.M. (2007): Learning from Data: Concept, Theory and Mehods, 2ed, Jogn Wiley -IEEE Press.

4. Farlov, S. (1984): Self-Organizing methods in Modeling: GMDH type Algorithm, Taylor and Francis.

5. Forsyth, R.(1989): Machine Learning: Princples and technics, London: Chapman and Hall.

6. Gilad-Bachrach, N. F.(2006): Large margin principles for feature selection“, In Guvon, G., Sikravesh, Z.(2006): Feature extraction, foundations and applications, SpringerVerlag.

7. Gilad-Bachrach, N. F.(2004): Margin based feature selection - theory and algorithms, InProc. 21st ICML.

8. Han, J., \& Camber, M. (2000): Data mining concepts and techniques, San Diego, USA: Morgan Kaufman.

9. Hart, A. (1989): Machine induction as a form of knowledge acquisition in knowledge engineering, in Forsyth. R. (1989): Machine Learning: Principles and techniques, 
Chapman and Hall, London.

10. Haussler, D. (1990): Probably approximately correct learning. In Proc. of the 8 th National Conference on Artificial Intelligence, pp. 1101-1108, Morgan Kaufmann.

11. Kantardzic, M. (2011): Data mining: concepts, models, methods, and algorithms. WilleyIEEE Press.

12.Kardaun, O.J.W.F., Itoh, S.I., Itoh, K., and Kardaun, J.W.P.F. (1993) Discriminant Analysis to Predict the Occurrence of ELMS in H-Mode Discharges, Nagoya, Japan: National Institute for Fusion Science.

13. Kohavi, R. (1995): A Study of Cross-validation and Bootstrap for Accuracy Estimation and Model Selection, Proc. of International Joint Conference on Artificial Intelligence.

14. Koteri, S., Lester, R. (2012): The Role of Accounting in the Financial Crisis: Lessons For The Future, Accounting Horizons, vol. 26. No.2, pp. 335-352.

15. Milojević, I., Vukoje, A., Mihajlović, M. (2013): Accounting consolidation of the balance by the acquisition method, Ekonomika poljoprivrede, vol. 60, no. 2, pp. 237-252, Društvo agrarnih ekonomista, Beograd, Srbija.

16. Quinlan, R. J., Cameron-Jonas, R.R. (1995): Introduction of Logic Programs: FOIL and Related Systems, New Generation Computing, vol 13, pp.287-312.

17. Stanojević, S., Đorđević, N., Volf, D. (2017): Primena kvantitativnih metoda u privređivanju poslovanja privrednih društava, ODITOR, vol. 3, No. 1, pp. 91-101. Centar za ekonomska i finansijska istraživanja, Beograd, Srbija.

18. Thanh, T.D., Moncef, G., \& Alexandros, I. (2017): Multilinear class-specific discriminant analysis, Aalborg, Pattern Recognition Letters, vol. 93, No. 3, pp. 131-136, Elsevier, Denmark.

19. Vukoje, A. (2013): Faktori egzistencije kao uslov stvaranja tržišne pozicije preduzeća, ODITOR, vol. 1, No. 5, pp. 27-37, Centar za ekonomska i finansijska istraživanja, Beograd, Srbija.

20. Written, I.H., Frank, E.(2005): Data Mining: Practical machine learning tools and techniques, 2 end edition, Morgan Kaufman, San Francisco.

21.Zhijin, J., Taijie, W., Yigang, X. \& Tao, H. (1994): The use of the discriminant analysis method for e $\pi \mu$ separation in BES, Netherlands: Nuclear Instruments and Methods in Physics Research. Section A, Accelerators, Spectrometers, Detectors and Associated Equipment, vol. 345, No. 3, pp. 541-548. 


\section{PRIMENA DISKRIMINACIONE ANALIZE U IZBORU TIPOVA ZEMLJIŠTA}

\section{Radovan Damnjanovič ${ }^{7}$, Snežana Krstič ${ }^{8}$, Milena Kneževič ${ }^{9}$, Svetislav Stankovićc ${ }^{10}$, Dejan Jeremic ${ }^{11}$}

\section{Rezime}

Čest problem, u agroekonomiji na primeru ispitne forme uzgoja biljaka, jeste odluka o tome da li biljka ili biljno potomstvo pripada grupi koja donosi profit kada se uzgaja u velikim ili malim zasadima.

Ponekad se odluke mogu doneti na osnovu jednog parametra, međutim, češće se ove dve grupe razlikuju na osnovu nekoliko promenljivih, od kojih svaka daje indikator o tome u kojoj se grupi pojedina biljka treba svrstati.Ovo je klasični problem klasifikovanja, gde je opšti problem da se pronađe funkcija raspodele.

Ključne reči: analiza, diferencijacija, tlo, vrste, biljka.

7 Docent Radovan Damnjanović, Vojna akademija, Univerzitet odbrane, Beograd, Pavla Jurišića Šturma 33, 11000 Beograd, Srbija, E-mail: radovandam78@gmail.com

8 Vanredni profesor Snežana Krstić, Ph.D., Vojna akademija, Univerzitet odbrane, Beograd, Pavla Jurišića Šturma 33, 11000 Beograd, Srbija, E-mail: snezanakrstic17@gmail.com

9 Milena Knežević, Univerzitet odbrane, Beograd, Pavla Jurišića Šturma 33, 11000 Beograd, Srbija.

10 Docent Svetislav Stanković, Vojna akademija, Univerzitet odbrane, Beograd, Pavla Jurišića Šturma 33, 11000 Beograd, Srbija.

11 Docent Dejan Jeremić, Sequester Employment, Palmotićeva ulica br. 22, 11000 Beograd, Srbija, E-mail: office@sequesteremployment.com

EP 2017 (64) 4 (1513-1521) 
ECONOMICS OF

AGRICULTURE

\section{CONTENT}

1. Adriana Radosavac, Desimir Knežević

ECONOMIC IMPORTANCE OF USE

OF PESTICIDES IN WHEAT PRODUCTION . . . . . . . . . . . 1323

2. Berhe Gebregewergs, Muuz Hadush

DOES CLIMATE CHANGE AFFECT PRICE OF VEGETABLES:

EVIDENCE FROM TIGRAI, NORTHERN MOST ETHIOPIA. . . . .1335

3. Grujica Vico, Aleksandra Govedarica-Lučić, Zoran Rajić, Radomir Bodiroga, Ivan Mičić, Silvija Zec Sambol, Marija Mičić

MULTI ATTRIBUTE ASSESSMENT APPROACH

IN VEGETABLE PRODUCTION . . . . . . . . . . . . . . 1355

4. Igor Trandafilović, Vesna Conić, Aleksandra Blagojević

IMPACT OF DEMOGRAPHIC FACTORS ON

ENVIRONMENTALLY CONSCIOUS PURCHASE BEHAVIOUR. . .1365

5. Imre Milán Harcsa

STUDY ON THE POTENTIAL OF SUBCONTRACT

PALINKA DISTILLATION . . . . . . . . . . . . . . 1379

6. Jelena Andrašić, Vera Mirović, Nada Milenković, Branimir Kalaš, Miloš Pjanić

IMPACT OF TAKEOVER PROCESS ON EMPLOYEES -

EVIDENCE FROM FOOD, RETAIL AND FINANCIAL SECTOR . . .1393

7. Jelena Birovljev, Danilo Đokić, Bojan Matkovski, Žana Kleut

ECONOMIC PERFORMANCES OF AGRICULTURE

OF CEFTA AND FORMER CEFTA COUNTRIES . . . . . . . . . . 1413

8. Jelena Marković, Svetlana Stevović

SUSTAINABILITY OF CHEMICAL SOIL QUALITY

IN SOUTHERN MORAVA RIVER VALLEY

IN CORELLATION WITH THE FLOODING $\ldots \ldots \ldots \ldots \ldots$ 
9. Mile Peševski, Zoran Milovančević

THE CHANGES IN THE USAGE OF AGRICULTURAL LAND

IN EASTERN REGION OF REPUBLIC OF MACEDONIA

BETWEEN $1991-2030 \ldots \ldots$. . . . . . . . . . . . . . . . . . . . . . .

10. Odjuvwuederhie Emmanuel Inoni, 'Oraye Dicta Ogisi, Felix Odemero Achoja

PROFITABILITY AND TECHNICAL EFFICIENCY IN HOMESTEAD

CATFISH PRODUCTION IN DELTA STATE, NIGERIA . . . . . . . 1449

11. Olja Munitlak - Ivanović, Jovan Zubović, Petar Mitić

RELATIONSHIP BETWEEN SUSTAINABLE DEVELOPMENT AND

GREEN ECONOMY - EMPHASIS ON GREEN FINANCE

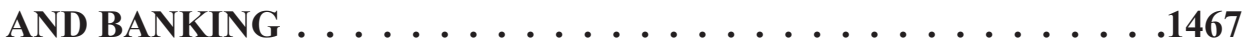

12. Petar Munćan, Dragica Božić

FARM SIZE AS A FACTOR OF EMLOYMENT AND INCOME

OF MEMBERS OF FAMILY FARMS . . . . . . . . . . . . . 1483

13. Rade Popović, Mira Kovljenić

EFFICIENCY OF WHEAT PRODUCTION ON FARMS

IN THE REPUBLIC OF SERBIA . . . . . . . . . . . . . . . . . . . . . . . . .

14. Radovan Damnjanović, Snežana Krstić, Milena Knežević, Svetislav Stanković,

Dejan Jeremić

THE DISCRIMINANT ANALYSIS APPLIED TO THE

DIFFERENTIATION OF SOIL TYPES . . . . . . . . . . . . 1513

15. Slavica Otović, Dunja Demirović, Kristina Košić, Aleksandra Vujko

FOSTERING ENTERPRENUERSHIP AT HIGH SCHOOLS:

A CASE OF RURAL AREAS IN VOJVODINA (SERBIA) . . . . . . .1523

16. Vladimir Ilić, Ivan Bauer, Anastazija Tanja Đelić, Aleksandar Nešković

INSTITUTIONAL SUPPORT FOR STRENGTHENING

ENTREPRENEURSHIP IN AGRICULTURAL PRODUCTION

OF THE REPUBLIC OF SERBIA . . . . . . . . . . . . . . . . . . . . . . . .

17. Boro Krstić, Zorica Vasiljević, Miroslav Nedeljković

INSURANCE CONTRACT AS THE BASIS FOR THE SAFETY OF

AGRICULTURAL PRODUCERS IN THE REPUBLIC OF SRPSKA • . 1555

18. Dejan Sekulić, Aleksandar Petrović, Vladimir Dimitrijević

WHO ARE WINE TOURISTS? AN EMPIRICAL INVESTIGATION

OF SEGMENTS IN SERBIAN WINE TOURISM . . . . . . . . . . . . . 
19. Milan Beslać, Ćorić Goran

FINANCIAL AND PRODUCTION ASPECTS OF GENETICALLY MODIFIED ORGANISMS $\ldots \ldots \ldots \ldots \ldots \ldots \ldots \ldots \ldots$

20. Mlađan Maksimović, Darjan Karabašević, Miodrag Brzaković, Pavle Brzaković THE EFFECTS RESULTING FROM THE APPLICATION OF THE CONCEPT OF THE SUSTAINABLE DEVELOPMENT OF RURAL TOURISM ON STARA PLANINA . . . . . . . . . . . . . . . .1595

21. Vesna Popović, Predrag Vuković, Milivoje Ćosić FOOD SAFETY AND QUALITY POLICY IN THE REPUBLIC OF SERBIA . . . . . . . . . . . . . . . . 1607

22. Radovan Pejanović, Danica Glavaš-Trbić, Mirela Tomaš-Simin PROBLEMS OF AGRICULTURAL AND RURAL DEVELOPMENT IN SERBIA AND NECESSITY OF NEW AGRICULTURAL POLICY . . . .1619

23. Saša Marković, Slavoljub Vujović, Aleksandar Damnjanović MARKETING AND HIGHER EDUCATION CONDITION IN SERBIA . . . . . . . . . . . . . . . . 1635

24. Semir Vehapi, Marina Milanović THE EFFECT OF MARKET ORIENTATION ON BUSINESS PERFORMANCE OF SERBIAN ORGANIC PRODUCERS . . . . . 1651

25. Suad Bećirović, Šemsudin Plojović, Enis Ujkanović, Senadin Plojović CHALLENGES AT STARTING AN AGRIBUSINESS IN THE HILLY MOUNTAINOUS REGIONS OF SOUTHWEST SERBIA . . . . . . . .1669

26. Vladimir Zakić, Vlado Kovačević, Jelena Damnjanović SIGNIFICANCE OF FINACIAL LITERACY FOR THE AGRICULTURAL HOLDINGS IN SERBIA . . . . . . . . . . 1687

27. Željko Bjelajac, Marijana Dukić Mijatović, Željko Vojinović PROTECTION OF LAND IN THE REPUBLIC OF SERBIA AND ECOLOGICAL SECURITY WITH REGARD TO STRATEGIC AND LEGAL FRAMEWORKS . . . . . . . . . .1703 